\title{
Characteristics of virophages and giant viruses
}

\author{
Beata Tokarz-Deptuła ${ }^{凶}$, Paulina Czupryńska², Agata Poniewierska-Baran ${ }^{1}$ and \\ Wiesław Deptuła²
}

1Department of Immunology, 2Department of Microbiology, Faculty of Biology, University of Szczecin, Szczecin, Poland

Five years after being discovered in 2003, some giant viruses were demonstrated to play a role of the hosts for virophages, their parasites, setting out a novel and yet unknown regulatory mechanism of the giant viruses presence in an aqueous. So far, 20 virophages have been registered and 13 of them have been described as a metagenomic material, which indirectly impacts the number of single- and multi-cell organisms, the environment where giant viruses replicate.

Key words: virophages, giant viruses, MIMIVIRE, Sputnik

Received: 14 June, 2018; revised: 21 August, 2018; accepted: 09 September, 2018; available on-line: 23 October, 2018

e-mail: beata.tokarz-deptula@usz.edu.pl

Abbreviations: ACMV, acanthamoeba castellanii mamavirus; ALM, ace lake mavirus; APMV, acanthamoeba polyphaga mimivirus; CroV, cafateria roenbergensis virus; DNA, deoxyribonucleic acid; dsDNA, double stranded DNA; DSLV, Dishui Lake virophage; dsRNA, double stranded RNA; IEM, independent entry mode; IRG1, immune responsive gene 1; NCLDV, nucleocytoplasmic large DNA viruses; OLV, organic lake virophage; ORF, open reading frames; QLV, Qinghai Lake virophage; PEM, paired entry mode; PCR, polymerase chain reaction; $P G V$, phaeocystis globosa virophage; $R N A$, ribonucleic acid; RNV, Rio Negro virophage; RVP, rumen virophage; SMBV, Samba virus; ssDNA, single-stranded DNA; ssRNA, single-stranded RNA; tRNA, transfer RNA; YSLV, Yellowstone Lake virophage

\section{VIROPHAGES}

Among the 20 virophages described so far, 13 are in the form of a metagenomic material, and the hosts were revealed for 16 virophages (Table 1). Out of the group of the 16 hosts, 8 giant viruses (items 1-6, 12 and 13 in Table 1) were characterized, with the other 8 hosts identified as the 'probable' giant viruses (items 7-11 and 18-20 in Table 1). Currently, the virophages are classified to belong to the Lavidaviridae family (Krupovic et al., 2016). Although they differ significantly between each other, they are considered to be satellite- or satellite-like viruses (Table 2).

Sputnik was the first virophage to be identified in 2008 in a Mamavirus - ACMV (Acanthamoeba castellanii mamavirus), a giant virus (Table 1) of the Mimivirus genus of Mimiviridae family (Table 3). The virus was found inside the protozoan Acanthamoeba (A.) castellanii, in a Paris water-cooling tower (Table 1). Research on ACMV Mamavirus revealed an eclipse phase, called Sputnik (from a Russian word meaning 'a companion in a journey'), to celebrate the first artificial satellite of the Earth (Taylor et al., 2014). Given the analogy with the term bacteriophages, it is also referred to as a virophage, which stands for a 'virus eater' (La Scola et al., 2008). Later, Sputnik virophage was demonstrated to infect the giant virus APMV (Acanthamoeba polyphaga) Mimivirus, that was identified in 2003 (Table 1) and belongs to the Mimivirus genus, Mimiviridae family (Table 3). It was found in the protozoan A. polyphaga in a water-cooling tower in Bradford (Table 1). Sputnik has a spherical dsDNA genome closed in a capsid with icosahedral symmetry, 50-74 nm in size, inside which there is a lipid membrane made of phosphatidylserine, which probably protects the genetic material of the virophage (Claverie et al., 2009; Desnues et al., 2012). Sputnik's genome has 18343 base pairs with 21 ORFs that encode proteins of 88 to 779 amino acids. They compose the capsids and are responsible for N-terminal acetylation of amino acids and transposases (Claverie et al., 2009; Desnues et al., 2012; Tokarz-Deptula et al., 2015). Sputnik's genome does not have an RNA-dependent DNA polymerase. Hence, in infection, Sputnik uses Mamavirus - ACMV or Minivirus - APMV synthesized polymerase (La Scola et al., 2008; Desnues et al., 2012).

Mavirus (Table 1) is a virophage that was identified in 2011 and infects a giant virus Cafateria roenbergensis (CroV) of the genus Cafateriavirus, family Mimiviridae ( $\mathrm{Ta}$ ble 3). Mavirus was isolated for the first time from the flagellate Cafateria roenbergensis that populates the coastal waters of Gulf of Mexico in Texas (Table 1). This virophage also has a spherical dsDNA genome, which probably encodes 20 proteins (Fischer et al., 2011; Sliwa-Dominiak et al., 2016), and a capsid with icosahedral symmetry that is similar to that identified in Sputnik (Fischer et al., 2011). The Mavirus virophage's genome is homologous to eukaryotic DNA transposons, which suggests that the virophages could indeed have been involved in their origin (Fischer et al., 2011; Desnues et al., 2012). Interestingly, virophages play an important role in the ecology of the protists' natural populations (Fischer et al., 2011; Desnues et al., 2012; Sliwa-Dominiak et al., 2016; Krupovic et al., 2016; Fischer et al., 2016).

The third discovered virophage was isolated in 2011 in the salty waters of Antarctica. It was OLV (Organic lake virophage), which preyed on an algae- infecting giant virus (no genus given), of a Phycodnaviridae family ( $\mathrm{Ta}$ ble 1). OLV, like the Sputnik, also has a double stranded DNA genome that is circular in shape and $26421 \mathrm{bp}$ in size and encodes 24 proteins which are $27-42 \%$ identical with the Sputnik proteins (Yau et al., 2011; Beklitz et al., 2016). The OLVs' effect on giant viruses infecting algae impacts their count and regulates organic matter in their aqueous environment (Yau et al., 2011).

Sputnik 2, which was discovered in 2012, has an 18338 bp, circular, double stranded DNA genome (Gaia et al., 2013; Beklitz et al., 2016), with a capsid that has icosahedral symmetry (Beklitz et al., 2016). It infects Lentille virus, a giant virus, genus Mimivirus, family Mimiviridae (Table 3 ), that was found in $A$. polyphaga eukaryote harvested from a contact lens fluid (Desnues et al., 2012). 
Table 1. Virophages and their "host" - giant viruses

\begin{tabular}{|c|c|c|c|c|}
\hline No. & $\begin{array}{l}\text { The name of the Virophages and the } \\
\text { year of finding }\end{array}$ & $\begin{array}{l}\text { Species, type or family } \\
\text { of giant viruses }\end{array}$ & $\begin{array}{l}\text { Host and place of occurance of giant } \\
\text { viruses }\end{array}$ & Reference \\
\hline \multirow{2}{*}{1.} & \multirow{2}{*}{ Sputnik (2008) } & Mamavirus (ACMV) & $\begin{array}{l}\text { Amoeba Acanthamoeba (A.) castellanii - } \\
\text { water of cooling tower } \\
\text { in Paris (France) }\end{array}$ & \multirow{2}{*}{$\begin{array}{l}\text { La Scola et al., } \\
2008\end{array}$} \\
\hline & & Mimivirus (APMV) & $\begin{array}{l}\text { Amoeba A. polyphaga - water of cooling } \\
\text { tower in Bradford } \\
\text { (England). }\end{array}$ & \\
\hline 2. & Mavirus (2011) & $\begin{array}{l}\text { Cafateria roenbergensis } \\
\text { virus (CroV) }\end{array}$ & $\begin{array}{l}\text { Flagellate Cafateria roenbergensis } \\
\text { - sea water in Texas coast (USA) }\end{array}$ & $\begin{array}{l}\text { Fischer \& Suttle, } \\
2011\end{array}$ \\
\hline 3. & $\begin{array}{l}\text { OLV (Organic Lake Virophage) } \\
(2011)\end{array}$ & Phycodnaviridae & $\begin{array}{l}\text { Algae (no name) - saline waters of } \\
\text { Antarctica Lake }\end{array}$ & Yau et al., 2011 \\
\hline 4. & Sputnik 2 (2012) & Lentille virus & $\begin{array}{l}\text { Amoeba A. polyphaga - contact lenses } \\
\text { liquid (France) }\end{array}$ & $\begin{array}{l}\text { Desnues et al., } \\
2012\end{array}$ \\
\hline 5. & Sputnik 3 (2013) & $\begin{array}{l}\text { Mimiviridae, probably } \\
\text { Mamavirus }\end{array}$ & $\begin{array}{l}\text { Amoeba A. polyphaga - soil samples } \\
\text { (France) }\end{array}$ & Gaia et al., 2013 \\
\hline 6. & $\begin{array}{l}\text { PGV (Phaeocystis globosa virophage) } \\
\text { - metagenomic material (2013) }\end{array}$ & $\begin{array}{l}\text { Phaeocystis globose } \\
\text { virus (PgV-16T) }\end{array}$ & $\begin{array}{l}\text { Algae Phaeocystis type - water of the } \\
\text { North Sea samples (coast of the Nether- } \\
\text { lands) }\end{array}$ & Santini et al., 2013 \\
\hline 7. & $\begin{array}{l}\text { YSLV } 1 \text { (Yellowstone Lake Virophage } \\
\text { 1) - metagenomic } \\
\text { material (2013) }\end{array}$ & \multirow{4}{*}{$\begin{array}{l}\text { Probably Phycodnaviri- } \\
\text { dae or Mimivirus }\end{array}$} & \multirow{4}{*}{$\begin{array}{l}{ }^{*} \text { Algae - water of the Yellowstone Lake } \\
\text { (USA) }\end{array}$} & \multirow{4}{*}{ Zhou et al., 2013} \\
\hline 8. & $\begin{array}{l}\text { YSLV } 2 \text { (Yellowstone Lake Virophage } \\
\text { 2) - metagenomic } \\
\text { material (2013) }\end{array}$ & & & \\
\hline 9. & $\begin{array}{l}\text { YSLV } 3 \text { (Yellowstone Lake Virophage } \\
\text { 3) - metagenomic } \\
\text { material (2013) }\end{array}$ & & & \\
\hline 10. & $\begin{array}{l}\text { YSLV } 4 \text { (Yellowstone Lake Virophage } \\
\text { 4) - metagenomic } \\
\text { material (2013) }\end{array}$ & & & \\
\hline 11. & $\begin{array}{l}\text { ALM (Ace Lake Mavirus) - } \\
\text { metagenomic material (2013) }\end{array}$ & $\begin{array}{l}\text { Probably } \\
\text { Mimiviridae }\end{array}$ & $\begin{array}{l}\text { *Protozoa (no name) - water of } \\
\text { Antarctica Lake }\end{array}$ & Zhou et al., 2013 \\
\hline 12. & RNV (Rio Negro virophage) (2014) & Samba wirus (SMBV) & $\begin{array}{l}\text { Amoeba A. castellanii - water of } \\
\text { the Negro River (Brazil) }\end{array}$ & $\begin{array}{l}\text { Campos et al., } \\
2014\end{array}$ \\
\hline 13. & Zamilon virophage (2014) & Mont1 wirus & $\begin{array}{l}\text { Amoeba A. polyphaga - soil samples } \\
\text { (Tunisia) }\end{array}$ & Gaia et al., 2014 \\
\hline 14. & $\begin{array}{l}\text { YSLV } 5 \text { (Yellowstone Lake Virophage } \\
\text { 5) - metagenomic } \\
\text { material (2015) }\end{array}$ & \multirow{3}{*}{ Not described } & \multirow{3}{*}{$\begin{array}{l}\text { No "host" for the virus-lake water in Yel- } \\
\text { lowstone Park (USA) }\end{array}$} & \multirow{3}{*}{ Zhou et al., 2015} \\
\hline 15. & $\begin{array}{l}\text { YSLV } 6 \text { (Yellowstone Lake Virophage } \\
\text { 6) - metagenomic } \\
\text { material (2015) }\end{array}$ & & & \\
\hline 16. & $\begin{array}{l}\text { YSLV } 7 \text { (Yellowstone Lake Virophage } \\
\text { 7) - metagenomic } \\
\text { material (2015) }\end{array}$ & & & \\
\hline 17. & $\begin{array}{l}\text { Zamilon } 2 \text { - metagenomic material } \\
(2015)\end{array}$ & Not described & $\begin{array}{l}\text { Probably amoeba Acanthamoeba } \\
\text { sp. - water in a poplar wood bioreactor } \\
\text { (USA)) }\end{array}$ & Beklitz et al., 2015 \\
\hline 18. & $\begin{array}{l}\text { RVP (Rumen virophage) - } \\
\text { metagenomic material (2015) }\end{array}$ & $\begin{array}{l}\text { Probably } \\
\text { Mimiviridae }\end{array}$ & $\begin{array}{l}\text { * Protozoa (no name) - sheep's rumen } \\
\text { (USA) }\end{array}$ & Yutin et al., 2015 \\
\hline 19. & $\begin{array}{l}\text { DSLV (Dishui Lake virophage) - } \\
\text { metagenomic material (2016) }\end{array}$ & $\begin{array}{l}\text { Probably } \\
\text { Phycodnaviridae }\end{array}$ & $\begin{array}{l}\text { *Algae (no name) - water of the Dishui } \\
\text { Lake (China) }\end{array}$ & Gong et al., 2016 \\
\hline 20. & $\begin{array}{l}\text { QLV (Qinghai Lake virophage) - } \\
\text { metagenomic material (2016) }\end{array}$ & $\begin{array}{l}\text { Probably } \\
\text { Phycodnaviridae }\end{array}$ & $\begin{array}{l}\text { *Algae (no name) - water of the Qinghai } \\
\text { Lake (Tibet) }\end{array}$ & Oh et al., 2016 \\
\hline
\end{tabular}

*supposed "host" for giant viruses 
Table 2. Selected feature of virophages and satellite viruses (satellite-like)

\begin{tabular}{|c|c|c|c|c|}
\hline No. & Feature & Virophages & Satellite viruses (satellite- like) & Reference \\
\hline 1. & Host & Giant viruses & $\begin{array}{l}\text { Mammals, plants in presence } \\
\text { of helper viruses }\end{array}$ & $\begin{array}{l}\text { Fischer et al., 2011; } \\
\text { Taylor et al., } 2014\end{array}$ \\
\hline 2. & $\begin{array}{l}\text { Impact on giant viruses or viru- } \\
\text { ses (helper viruses) }\end{array}$ & $\begin{array}{l}\text { Negatively impact on giant } \\
\text { viruses }\end{array}$ & $\begin{array}{l}\text { No negatively impact on hel- } \\
\text { per viruses }\end{array}$ & Taylor et al., 2014 \\
\hline 3. & $\begin{array}{l}\text { Impact of virophages on host of } \\
\text { giant viruses (protozoa, algae) } \\
\text { and impact of satellite } \\
\text { viruses on host of viruses (mam- } \\
\text { mals and plants) }\end{array}$ & No interactions & Negatively or no interactions & $\begin{array}{l}\text { Taylor et al., 2014; } \\
\text { Tokarz-Deptuła et al., } \\
2013\end{array}$ \\
\hline 4. & Place of replication & „Factories of giant viruses” & $\begin{array}{l}\text { Cell nucleus of eukaryotic } \\
\text { organisms }\end{array}$ & $\begin{array}{l}\text { Colson et al., 2010; } \\
\text { Abergel et al., } 2015\end{array}$ \\
\hline 5. & Type of genetic material & dsDNA & ssRNA, dsRNA and ssDNA & Krupovic et al., 2016 \\
\hline 6. & Genome size & $18,0-19,0$ thousand bp & 11,0 thousand $n t$ & Krupovic et al., 2016 \\
\hline 7. & $\begin{array}{l}\text { Differentiation in genome bu- } \\
\text { ilding }\end{array}$ & $\begin{array}{l}\text { High degree of diversity, be- } \\
\text { cause they have sequences } \\
\text { from eukaryotes, } \\
\text { including algae and giant } \\
\text { viruses }\end{array}$ & $\begin{array}{l}\text { Typical diversity - only viral } \\
\text { sequences exist }\end{array}$ & $\begin{array}{l}\text { Fischer et al., 2011; } \\
\text { Desnues et al., 2012; } \\
\text { Krupovic et al., } 2016\end{array}$ \\
\hline 8. & Size of capsid & $50-70 \mathrm{~nm}$ & about $20 \mathrm{~nm}$ & Krupovic et al., 2016 \\
\hline 9. & Capsid organization & $\begin{array}{l}\text { Not typical because for exam- } \\
\text { ple Sputnik virophage have a } \\
\text { double-layered lipid } \\
\text { film under capsid }\end{array}$ & Typical & Yutin et al., 2015 \\
\hline 10. & Origin & $\begin{array}{l}\text { Unclear, but probably from eu- } \\
\text { karyotes, bacteria and archaea }\end{array}$ & Unclear & $\begin{array}{l}\text { Fischer et al., 2011; } \\
\text { Desnues et al., 2012; } \\
\text { Krupovic et al., } 2016\end{array}$ \\
\hline
\end{tabular}

Another virophage, called Sputnik 3, was identified in 2013. It has an 18338 bp, circular, double stranded DNA genome (Gaia et al., 2013; Beklitz et al., 2016), with a capsid that also has an icosahedral symmetry (Beklitz et al., 2016). Virophage Sputnik 2 was isolated for the first time from a soil sample taken outside Marseilles in France and containing $A$. polyphaga amoeba (Table 1). To extract Sputnik 3 from its host giant virus, a co-culture of 20 giant virus strains of Mimiviridae family was used as a reporter. Sputnik 3 was then found in a soil sample filtrate added to the culture (giant viruses + amoebae being their hosts), using PCR (Gaia et al., 2013). Thus, it was assumed that the virophage replicates only in Mamavirus - ACMV co-culture, genus Mimivirus, family Mimiviridae (Table 3). Now, Sputnik, Sputnik 2 and 3 are known to replicate in so-called 'giant virus replication factories' (Table 1). Although they colonize different giant viruses, all three Sputniks share as much as $99 \%$ of their DNA (Table 1).

PGV (Phaeocystis globosa virophage) was identified in 2013 (Table 1) in Phacocystis globosa giant virus (PgV-16T), genus Prymneovirus, family Phycodnaviridae (Table 3), which infected Phaeocystis algae in Dutch coastal waters of the North Sea (Table 1). The virophage has a circular double stranded DNA of 19527 bp, closed in a capsid of an undefined symmetry. It encodes 16 proteins, some of which have homologs in Mavirus or OLV (Santini et al., 2013). Since no genes encoding capsid proteins have been found in PGV's genome, it has been suggested that it replicates as a linear plasmid in $\mathrm{PgV}-16 \mathrm{~T}$ particles or is integrated in its host virus genome as a provirophage (Santini et al., 2013). PgV virophage replicates in PgV165 giant virus particle factories like the Sputniks (Santini et al., 2013).

Five more new metagenomic sequences were identified in 2013. They were defined as ALM and YSLV14 virophages (Table 1). They all have circular double stranded DNA and icosahedral symmetry of the capsid (Beklitz et al., 2016; Yutin et al., 2015). One of the sequences called ALM (Ace Lake Mavirus) is 17767 bp long and encodes 22 ORFs, 14 of which are homologous to those found in Mavirus virophage (Zhou et al., 2013; Beklitz et al., 2016). ALM probably infects Mimiviridae giant viruses found in (unspecified) eukaryotes in Antarctica lakes (Table 1).

Four successive metagenomic sequences, defined as YSLV 1-4 virophages, were found in the water samples from the Yellowstone Lake (USA) (Table 1). They were homologous to OLV with replication mechanism similar to that of YSLV 1-4 in the algae infecting Phycodnaviridae giant virus hosts. Giant viruses, genus Mimivirus, family Mimiviridae, were also suggested as their eukaryotic hosts (Tables 1 and 3). 
Table 3. Giant viruses - host of virophages

No. Family of giant viruses $\begin{gathered}\text { Type of giant } \\ \text { viruses }\end{gathered} \quad$ Species of viruses and place of occurance Refences

\begin{tabular}{|c|c|c|c|c|}
\hline \multirow{6}{*}{1.} & \multirow{6}{*}{ Mimiviridae* } & \multirow{5}{*}{ Mimivirus } & $\begin{array}{l}\text { Mimivirus Acanthamoeba polyphaga mimivirus (APMV) - } \\
\text { 2003, amoeba - Acanthamoeba (A.) polyphaga }\end{array}$ & La Scola et al., 2003 \\
\hline & & & $\begin{array}{l}\text { Mamavirus Acanthamoeba castellani mimivirus (ACMV) - } \\
\text { 2008, } \\
\text { amoeba - A. castellani }\end{array}$ & La Scola et al., 2008 \\
\hline & & & Lentille virus - 2012, amoeba - A. polyphaga & Desnues et al., 2012 \\
\hline & & & Samba virus (SMBV) - 2014, amoeba - A. castellani & Campos et al., 2014 \\
\hline & & & Mont1 - 2014, amoeba - A. polyphaga & Gaia et al., 2014 \\
\hline & & Cafateriavirus & $\begin{array}{l}\text { Cafateria roenbergensis virus (CroV) - 2010, flagellate Cafa- } \\
\text { teria roenbergensis }\end{array}$ & Fischer et al., 2011 \\
\hline \multirow{2}{*}{2.} & \multirow{2}{*}{ Phycodnaviridae** } & Prymneovirus & $\begin{array}{l}\text { Phaeocystis globosa virus (PgV-16T) - 2013, algae Phaeocy- } \\
\text { stis globosa }\end{array}$ & $\begin{array}{l}\text { Santini et al., 2013; } \\
\text { Wilson et al., } 2009\end{array}$ \\
\hline & & No data & No species - 2011, sea algae (no name) & Yau et al., 2011 \\
\hline
\end{tabular}

* In this family could be included giant viruses (not described), which colud be the host of virophages Sputnik 3 and probably megaviruses (without specifying the family and genus), the "hosts" of the virophages ALM and RVP and giant viruses (Mimivirus), the "hosts" of virophages YSLV1, YSLV2, YSLV3, YSLV4 (Table 1). **This family should probably include megaviruses, without specifying the family and type that are the "hosts" of the virophage YSLV1, YSLV2, YSLV3, YSLV4 and DSLV and QLV (Table 1).

RNV (Rio Negro virophage) was identified in 2014 in the Negro River in the Amazon rainforest in Brazil. It was found in $A$. castellanii infected with Samba, a SMBV giant virus, of the genus Mimivirus, family Mimiviridae (Table 1 and 3). It has double stranded DNA. No data is available, though, on whether it has a circular or linear shape. RNV's capsid was demonstrated to have icosahedral symmetry with a diameter of approximately $35 \mathrm{~nm}$ (Campos et al., 2014; Beklitz et al., 2016). Through the infection of Samba giant virus replicating in $A$. castellanii hosts, RNV causes abnormal shape of Samba's capsid and reduces its standard concentration in amoebas by over 80\% (Yau et al., 2011; Krupovic et al., 2016). RNV is also responsible for the defective capsid shape of APMV giant virus infecting $A$. castellanii hosts (Campos et al., 2014).

Zamilon virophage was isolated in 2014 from the soil samples from Tunisia (Table 1). It infected a Mont1 giant virus, genus Mimivirus, family Mimiviridae (Table 3) in its A. polyphaga host. It contains a double stranded spherical DNA genome of 17276 bp with 20 ORFs (Gaia et al., 2014; Beklitz et al., 2016), some of which encode proteins that are homologous to other known virophage proteins, ATPases, helicases and transposases (Gaia et al., 2014). According to Gaia and others (Gaia et al., 2014), Zamilon has a $70-76 \%$ genetic identity with Sputnik, Sputnik 2, Sputnik 3 and Megavirus chilensis giant virus. Interestingly, it is the only virophage that infects lineage $\mathrm{C}$ of Mimiviridae giant viruses (Santini et al., 2013, Campos et al., 2014; La Scola et al., 2008; Gaia et al., 2013; Yau et al., 2011; Fischer et al., 2011; Zhou et al., 2013; SliwaDominiak et al., 2016; Desnues et al., 2012). All the other virophages characterized so far (Table 1) infect lineage A giant viruses of Mimiviridae family as well (Campos et al., 2014; La Scola et al., 2008; Gaia et al., 2013; Desnues et al., 2012). Zamilon has a 50-60 nm icosahedral capsid. Zamilon causes abnormal capsid shape in the infected Mont1 giant viruses. However, it does not affect neither their replication, nor the lytic ability (Gaia et al., 2014).

Three new virophages, YSLV5, YSLV6 and YSLV7, were identified in 2015 as a metagenetic material (Zhou et al., 2015) in the Yellowstone Lake (US). They showed genetic homology to Zamilon. Their DNA was double stranded and spherical and their capsids were probably icosahedral (La Scola et al., 2008; Gaia et al., 2013). Their genomes were 22000-29000 bp in size and contained 26 to 32 ORFs (Zhou et al., 2015; Beklitz et al., 2016). No giant viruses or organisms were identified to be the hosts to YSLV5, YSLV6 and YSLV7 (Table 1). The YSLV5-7 virophages show a significant homology to YSLV1, YSLV2, YSLV3 and YSLV4, which were isolated in the same waters of Yellowstone Lake back in 2013 (Table 1).

A homologous to Zamilon strain of dsDNA discovered in 2015 was named Zamilon 2 (Table 1). Although no giant virus was implicated, a probable host of Zamilon 2 is Acanthamoeba sp. giant virus (Table 1), first found in a bioreactor in the state of New York (US). Zamilon 2 virophage has a capsid that is probably icosahedral (Beklitz et al., 2016; Yutin et al., 2015). Its genome is only $6616 \mathrm{bp}$ in size, and 392 base pairs are identical with Zamilon genome (Beklitz et al., 2015).

RVP (Rumen virophage) was identified in a metagenetic material in 2015. It probably infects Mimiviridae giant viruses that replicate in (unspecified) eukaryotic hosts in the sheep rumen (Table 1). RVP probably has an icosahedral capsid (Beklitz et al., 2016; Yutin et al., 2015). Its linear genome is different from the genomes of the other virophages and owing to this it is referred to as a 'hybrid virophage' - a combination of a virophage and 
Table 4. Selected feature of giant viruses and viruses ("classic" viruses)

\begin{tabular}{|c|c|c|c|c|}
\hline No. & Feature & Giant viruses & $\begin{array}{l}\text { Viruses } \\
\text { („classical" viruses) }\end{array}$ & References \\
\hline 1. & Genetic material & Doubled-strended DNA & $\begin{array}{l}\text { DNA or RNA, } \\
\text { single or double- } \\
\text { stranded, circular }\end{array}$ & $\begin{array}{l}\text { La Scola et al., 2003; } \\
\text { Fischer et al., } 2011\end{array}$ \\
\hline 2. & Size of genome & $1.181 \mathrm{Mb}$ & $0.035 \mathrm{Mb}$ & $\begin{array}{l}\text { La Scola et al., 2003; Campos et al., } \\
\text { 2014; Monti et al., 2008; Gaia et al., } \\
\text { 2014; Fischer et al., 2011; Wilson } \\
\text { et al., 2009; Desnues et al., 2012; } \\
\text { Abergel et al., } 2015\end{array}$ \\
\hline 3. & The content of the genome & $\begin{array}{l}\text { Genes of viral, prokaryotic, ar- } \\
\text { chaeonic and eukaryotic origin }\end{array}$ & Typical for viruses & $\begin{array}{l}\text { Raoult et al., 2004; Suzan-Monti et } \\
\text { al., 2007; Claverie et al., 2009; Corti- } \\
\text { nes et al., 2015; Abergel et al., } 2015\end{array}$ \\
\hline 4. & $\begin{array}{l}\text { DNA repair genes, transcrip- } \\
\text { tion factors, genes respon- } \\
\text { sible for protein buffering } \\
\text { and modification, mRNA } \\
\text { synthesis genes, genes en- } \\
\text { coding tRNA polysaccharide } \\
\text { synthesis genes and } \\
\text { mobile genetic elements }\end{array}$ & $\begin{array}{l}\text { They have them, which determi- } \\
\text { nes the mosaicism of their geno- } \\
\text { me, gives it instability and can } \\
\text { expand their infectious spectrum }\end{array}$ & Absent & $\begin{array}{l}\text { Suzan-Monti et al., 2006; Suzan- } \\
\text {-Monti et al., 2007; Claverie et al., } \\
\text { 2009; Cortines et al., 2015; Abergel } \\
\text { et al., } 2015\end{array}$ \\
\hline 5. & $\begin{array}{l}\text { Presence of } \\
\text { atypical elements }\end{array}$ & $\begin{array}{l}\text { Presence for example trans- } \\
\text { posons, inteins, introns, rope } \\
\text { plasmids }\end{array}$ & Absent & $\begin{array}{l}\text { Sharma et al., 2016; Suzan-Monti et } \\
\text { al., 2006; Xiao et al., 2009; Raoult et } \\
\text { al., 2004; Colson et al., 2010; Santini } \\
\text { et al., 2013; Claverie et al., } 2016\end{array}$ \\
\hline 6. & Replication & „Factories of giant viruses” & $\begin{array}{l}\text { In cell nucleus, but } \\
\text { also in cytoplasm of } \\
\text { macro organism }\end{array}$ & $\begin{array}{l}\text { Colson et al., 2010; } \\
\text { Abergel et al., } 2015\end{array}$ \\
\hline 7. & Size of capsid & $200-1000 \mathrm{~nm}$ & $\sim 17-200 \mathrm{~nm}$ & $\begin{array}{l}\text { La Scola et al., 2003; } \\
\text { Colson et al., } 2010\end{array}$ \\
\hline 8. & Capsid organization & $\begin{array}{l}\text { Capsid coverd with } 150 \mathrm{~nm} \text { of } \\
\text { peptydoglycan-based fibers, } \\
\text { glycosylation glycoproteins }\end{array}$ & $\begin{array}{l}\text { Typical for } \\
\text { "classic" viruses" }\end{array}$ & $\begin{array}{l}\text { La Scola et al., 2003; Suzan-Monti et } \\
\text { al., 2006; Raoult et al., 2004; Corti- } \\
\text { nes et al., 2015; Abergel et al., } 2015\end{array}$ \\
\hline 9. & Resistance system & $\begin{array}{l}\text { MIMIVIRE similar to CRISP-Cas } \\
\text { mechanism } \\
\text { commonly present in bacteria } \\
\text { and archaea }\end{array}$ & Absent & Levasseuer et al., 2016 \\
\hline 10. & Host - place of „living” & $\begin{array}{l}\text { Water - protozoa (amoeba, } \\
\text { flagellate), algae, sponge, coral, } \\
\text { mollusc, insects. Soil (desert, } \\
\text { prairies, tundra) - amoeba.Mam- } \\
\text { mals - human and animals } \\
\text { ( sheep, cattle) }\end{array}$ & $\begin{array}{l}\text { Eukaryotes (including } \\
\text { mammals), prokary- } \\
\text { otes and archea }\end{array}$ & $\begin{array}{l}\text { La Scola et al., 2003; Santini et al., } \\
\text { 2013; Campos et al., 2014; Monti et } \\
\text { al., 2008; Gaia et al., 2014; Fischer } \\
\text { et al., 2011; Wilson et al., 2009; } \\
\text { Desnues et al., 2012; Abergel et al., } \\
2015\end{array}$ \\
\hline
\end{tabular}

large polinton, DNA transposon, i.e. giant virus transpoviron DNA (Yutin et al., 2015).

New metagenetic material, defined later as two novel virophages, was isolated in Asia (Table 1). The first was DSLV (Dishui Lake virophage) with a circular double stranded DNA genome, 28788 bp in size, that contained 28 ORFs (Gong et al., 2016; Beklitz et al., 2016), and showed a significant homology to all the virophages identified in Yellowstone Lake (YSLV 1-7) (Table 1). It was particularly homologous to YSLV3 and OLV (Gong et al., 2016; Beklitz et al., 2016). DSLV was extracted from Dishui Lake in Shanghai, China. Although it was assigned no giant virus host, the probable candidate may be Phycodnaviridae virus that infects (unspecified) algae (Table 1). DSLV's genome has 23379 bp and contains 25 ORFs (Oh et al., 2016, Beklitz et al., 2016).

QLV (Qinghai Lake virophage) was the second virophage to be found in the region (Table 1). It is most closely related to OLV and YSLV (Gong et al., 2016; Beklitz et al., 2016). It was isolated from Qinghai Lake in Tibetan mountains. Like DSLV, QLV probably infects Phycodnaviridae giant viruses found in unspecified algae (Tables 1 and 3).

\section{GIANT VIRUSES, WHICH CAN BE VIROPHAGES' HOSTS}

The studies on giant viruses - megaviruses, including Mimiviridae and Phycodnaviridae families that act as hosts for virophages, showed that they are abundant in the natural environment and have properties that (classic) viruses do not display (Table 4). Giant viruses are also called nucleocytoplasmic large DNA viruses (NCLDVs). Prior to isolation of Mimiviridae viruses that act as virophage hosts, several other viruses were classified as giant viruses, including PgV-16T viruses of family Phy- 
codnaviridae, genus Prymneovirus that host virophages but replicate in algae (Table 3 ), the viruses that infect vertebrates from family Asfarviridae, the viruses that infect vertebrates and insects from family Poxviridae and the viruses from family Iridoviridae that infect eukaryotes found in aqueous environment (La Scola et al., 2003).

Six species of giant viruses, including APMV, ACMV, Lentilevirus, SMBV, Mont1, CroV, and eight other unspecified viruses were extracted from Mimiviridae family (Table 1). They replicate in eukaryotes (amoebae and flagellates) and belong to Mimivirus and Cafateriavirus genera (Table 3). They have linear or circular double stranded DNA (La Scola et al., 2003; Campos et al., 2014; La Scola et al., 2008; Gaia et al., 2014; Yau et al., 2011; Boughalmi et al., 2013) and a large genome ranging from 0.6 to over $1 \mathrm{Mb}$ (La Scola et al., 2003; Campos et al., 2014; La Scola et al., 2008; Gaia et al., 2014; Wilson et al., 2009; Desnues et al., 2012; Abergel et al., 2015). The viruses were demonstrated to have MIMIVIRE - genes regulating immunity system against virophages. They are the common genes found in (classical) viruses, giant virus particles, including transpovirons, polintons (TokarzDeptula et al., 2015), genes typical of bacteria, archaea and eukarya, i.e. transposons, inteins, introns and linear plasmids. The giant viruses that host virophages have a mosaic-like genome (Sharma et al., 2016; Xiao et al., 2009; Suzan-Monti et al., 2006; Raoult et al., 2004; Colson et al., 2010; Santini et al., 2013; Claverie et al., 2016). Abergel and others (Abergel et al., 2015), meaning that the genome contains approximately $21 \%$ of genes that originate from the eukaryotic, prokaryotic and archaeal organisms.

The first giant virus of Mimiviridae family is Acanthamoeba castellanii Mamavirus (a strain of giant ACMV, genus Mimivirus), from which Sputnik was for the first time isolated in 2008 (La Scola et al., 2008) (Table 1). The Mamavirus was discovered in 2003 and called mimivirus ("mimicking microbe") in the amoeba Acanthamoeba polyphaga residing in a Bradford water-cooling tower (England) (Table 1).

APMV was at first called Bradfordcoccus owing to its resembling of the Gram-positive cocci. It was identified in 1992 and genetic analysis was not available at that time (La Scola et al., 2003). Later on, the electron microscopy methods (La Scola et al., 2003) showed that it has properties similar to those of a virus. A new family of Mimiviridae (Table 2) was identified as a part of the NCLDV superfamily (La Scola et al., 2003). The mimivirus has icosahedral capsid, approximately $440 \mathrm{~nm}$ long. It does not seem to have an outer envelope. The virus replicates in amoeba's cytoplasm creating so-called 'viral factories' (Colson et al., 2010; Abergel et al., 2015). On its surface, it has the fibrilis (collagen) protrusions (Suzan-Monti et al., 2006; Raoult et al., 2004), that are covered with 150 $\mathrm{nm}$ fibers made of peptidoglycan, an element common to bacteria (Abergel et al., 2015). This layer is probably responsible for the virus's adhesion to amoeba cells during the infection (Rodriggues et al., 2015). It also regulates virophage adhesion to the virus during their common entry into amoeba cells (Taylor et al., 2014). Like all Mimiviridae family, mimivirus genome consists of the linear dsDNA and is up to $1181 \mathrm{Mbp}$ long, carrying 1262 potential genes. It contains the capsid genes, infectioninducing genes and, never observed in (classic) viruses, the DNA repair genes, transcription factors, mRNA synthesis genes (including genes encoding tRNA), genes of mobile genetic elements, polysaccharide synthesis genes that also include peptidoglycan, and 911 protein-coding genes, including protein folding and protein modification genes (Raoult et al., 2004; Suzan-Monti et al., 2007; Claverie et al., 2009; Rodriggues et al., 2015; Tokarz-Deptula et al., 2013; Abergel et al., 2015). All these elements of APMV result in the mosaic character of its genome and make the genome unstable, which may broaden the virus's spectrum of infection (Raoult et al., 2004; SuzanMonti et al., 2007; Claverie et al., 2009; Rodriggues et al., 2015; Tokarz-Deptula et al., 2013; Abergel et al., 2015). APMV infects Acanthamoeba polyphaga usually through phagocytosis. However, the mechanism of the virus's replication inside amoebae has not been explained yet (Suzan-Monti et al., 2006).

Mamavirus - ACMV (Acanthamoeba castellanii mamavirus) is a strain of APMV virus that has a nucleoid which is $99 \%$ identical with that of APMV (La Scola et al., 2008). As mentioned above, the Sputnik virophage was isolated from it (Table 1). The new giant virus called A. castellanii mamavirus (ACMV) was isolated in 2008 from Acanthamoeba castellanii found in a cooling water tower, and also in many pulmonary infections in patients from a Paris hospital (Table 1). Like Mimivirus - APMV, the ACMV mamavirus has an icosahedral capsid (Zhou et al., 2015; Raoult et al., 2010) and replicates in the viral factories. Its genome is $1191 \mathrm{Mbp}$ long linear double stranded DNA. ACMV is therefore 10000 bp longer than APMV, although at the end of the 5th section it has approximately 13000 bp which were not found in AMPV (Zhou et al., 2015).

Apart from the Mimivirus - APMV and Mamavirus - ACMV (Table 1), the other giant viruses that act as virophage hosts include a Lentille virus which hosts Sputnik 2, a probable Mamavirus - ACMV which hosts Sputnik 3, a Samba virus which hosts Rio Negro virophage, a Mont1 virus which hosts Zamilon (Table 1), a virophage of genus Mimivirus, family Mimiviridae (Table 3) which, like giant viruses (APMV and ACMV), replicate in $A$. polyphaga and $A$. catellanii amoebae. The Sputnik 2, Sputnik 3, Rio Negro and Zamilon virophages replicate in virus replication factories in amoeba's cytoplasm and were found parasitizing 4 species of giant viruses, including Lentille, Mamavirus - ACMV, Samba and Mont1 (Table 1). All the virophages have a linear double stranded DNA genome closed in an icosahedral capsid (La Scola et al., 2003; Sharma et al., 2016; Xiao et al., 2009; Raoult et al., 2004; Campos et al., 2014; SuzanMonti et al., 2007; Saadi et al., 2013a; Saadi et al., 2013b; La Scola et al., 2008; Gaia et al., 2014; Tokarz-Deptula et al., 2013; La Scola et al., 2005).

CroV (Cafateria roenbergensis virus) is another representative of the giant viruses. It comes from a family of Mimiviridae, genus Cafateriavirus, that hosts Mavirus virophage, found in flagellate Cafateria roenbergensis (Tables 1 and 3). Crov has a linear double stranded DNA genome of 0.78 $\mathrm{Mb}$, closed in an icosahedral capsid. Like other giant viruses of the genus Mimivirus, family Mimiviridae that were discussed above, $\mathrm{CroV}$ replicates in viral factories in $\mathrm{Ca}$ fateria roenbergensis cytoplasm. Mimiviridae family of viruses includes unspecified giant viruses that host ALM, RVP, YSLV1-YSLV4 virophages (Tables 1 and 3). The latter may also be hosted by Phycodnaviridae giant viruses (Tables 1 and 3).

PgV-16T (Phaeocystis globosa virus) from the genus Prymneovirus of the Pycodnaviridae family (Table 3) infects algae and is an obligate host of the virophages. PgV-16T acts as host for PGV (Phaeocystis globosa virophage) (Table 1). Similar to other Mimiviridae, this giant virus has a linear double stranded DNA genome and replicates in the algae cytoplasm. Its icosahedral capsid is smaller (by up to $220 \mathrm{~nm}$ ) than that of the Mimiviridae viruses. PgV-16T 
genome is $470000 \mathrm{bp}$ long and contains a duplication of the two types of virus core genes packing ATPases and RNA polymerases (Santini et al., 2013; Wilson et al., 2009; Baudoux et al., 2005). PgV-16T is similar to APMV and $\mathrm{CroV}$ from the Mimiviridae family, which host virophages and contain DNA sequences common for bacteria, archaea and eukaryotes (Santini et al., 2013). Giant viruses of the Phycodnaviridae family, (no genus available) are reported to host OLV (Organic lake virophage), DSLV (Dishui lake virophage), QLV (Qinghai lake virophage) and YSLV1-4 virophages, likewise the Mimiviridae viruses.

To sum up the data on giant viruses that act as hosts or probable hosts for 16 out of the total of 20 virophages identified to date (Table 1 ), the 5 species of giant viruses were found in amoebae, 1 species in flagellate, 7 probable (unknown) Mimiviridae giant viruses in eukaryotes and 8 types of Phycodnaviridae viruses in algae (Tables 1 and 3). The giant viruses from Mimiviridae family (Table 3) were found not only in amoebae and flagellates (Table 1), but they can also infect sponges, coral, sheep, cattle and people (Yutin et al., 2015; Saadi et al., 2013a; Saadi et al., 2013b; La Scola et al., 2005; Almeida et al., 2017; LaScola et al., 2014; Raoult et al., 2010; Kutikhin et al., 2014). They were demonstrated to constitute a part of the microbiome of the human respiratory system, as they were identified in bronchoscopic samples of the healthy people as well as in the samples taken from patients diagnosed with pneumonia (Saadi et al., 2013a; Saadi et al., 2013b; LaScola et al., 2005; Almeida et al., 2017; Raoult et al., 2010; Kutikhin et al., 2014). They were secondarily identified in the blood of the patients suffering from respiratory diseases. That would explain the pneumonia cases in the patients from Bradford and Paris, where the first Mimiviridae viruses: Mimivirus - APMV and Mamavirus ACMV, were discovered (Saadi et al., 2013a; Saadi et al., 2013b; LaScola et al., 2005; Almeida et al., 2017; Raoult et al., 2010; Kutikhin et al., 2014). Currently (Almeida et al., 2017), the APMV Mimivirus was demonstrated to trigger a novel type of immune response in the human body, regulated by the activity of interferons (IFNs), and IFN- $\beta$ in particular. The infection with APMV was shown to facilitate IFN- $\beta$ activity and induce immune responsive gene 1 (IRG1) in macrophages, resulting in itaconic acid release which activated antiviral and antibacterial immunity and metabolic processes (Almeida et al., 2017). Marsellieviridae giant viruses were isolated from the human blood, macrophages and lymphoid tissue as well as from the Limnoperna fortunei bivalvia and Eristalis tenax larva (Almeida et al., 2017; Dos Santos et al., 2016; Boughalmi et al., 2013), which shows that giant viruses are quite common risk factors in the environment.

\section{INTERACTIONS BETWEEN VIROPHAGES AND GIANT VIRUSES}

To examine the interactions between virophages and their Mimiviridae and Phycodnaviridae giant viruses hosts, it is important to understand the way virophages enter viruses and the way giant viruses infected with virophages enter their specific hosts, i.e. protozoa (amoebae and flagellates), algae and mammals. Because virophages can only replicate in the "viral factories" of the giant viruses, the mechanism of their co-infections is important to know.

Giant virus infection mechanisms were elucidated by Taylor and coworkers (Taylor et al., 2014), who used a mathematical model to show the two probable ways in which virophage - infected giant viruses enter amoebae and flagellates (Fig. 1). The first way is called IEM (independent entry mode) and is common for Mavirus virophage and its giant virus - CroV. They both independently enter a protozoan where they later both replicate (Fig. 1a). The other way, called PEM (paired entry mode), is thought to be used by Sputnik virophage and its giant virus Mimivirus (APMV). In this way, the co-infection occurs when the giant virus and virophage are entangled and together enter the host organism - A. polyphaga. This way consists of two phases. First, Sputnik adheres to Mimivirus (APMV) and this complex successively enters the amoeba via phagocytosis. This entry stage was confirmed with electron microscope photos showing Mamavirus (ACMC) giant virus and its virophage - Sputnik occurring in the phagocytic vacuole (Desnues et al., 2010). Forming of a "complex" of the virophage and giant virus, is also enabled by the long collagen fibers appearing on the surface of Mamavirus (ACMC). The complex (entanglement) is easily absorbed by amoeba A. castellanii (Xiao et al., 2009; Taylor et al., 2014). This hypothesis was confirmed by the study of Boyer and others (Boyer et al., 2011), which showed that virophages (Sputnik), were not able to penetrate and replicate when co-cultured with the giant viruses (Mamavirus) without fibers. This suggests the important role of these fibers in the formation of giant virus - virophage complex and in their penetration into the host via PEM (Desnues et al., 2010; Taylor et al., 2014). In the second phase of PEM pathway, the Mimivirus (APMV) sheds its capsid and the genome of the entangled virophage enters the so-called "viral replication factories", where the virophages are replicated (Taylor et al., 2014) (Fig. 1b).

Replication of the virophages starts 3-6 hours after the entry of a giant virus to the host cell, i.e. when its eclipse phase has completed (Desnues et al., 2010; Marie et al., 2016). The replication of a giant virus involves laying and creating the offspring virions, which remain in eukaryotic (amoebae and flagellates) cells' cytoplasm until their lysis (Desnues et al., 2010; Marie et al., 2016). Currently (Taylor et al., 2014), it has been suggested that the infection of protozoans with a virophage and a giant virus relies on the PEM pathway. Another proposed way of the eukaryotic infection is when a giant virus and a virophage replicate independently in the environment. When the protozoa come into contact, the infection is passed over to the other organisms (Yau et al., 2011). Taylor and coworkers (Taylor et al., 2014) pointed out that both IEM and PEM entry pathways of the virophage-infected giant viruses to amoebae and flagellates depend equally on the same three elements - a host (amoeba), a giant virus and a virophage. However, studies by Yau and coworkers (Yau et al., 2011), showed the association of a giant virus and a virophage can be present in a predator-prey context (predator-prey system), where the increase in the number of virophages can be, theoretically, independent of the final host (Fig. 1c). However, it should be remembered, that the virophages require the presence of both - the host and the giant virus for their own replication. Therefore, such a theory is debatable, because no replication of virophages, without co-infection with the giant virus, has ever been observed in nature, in any eukaryotic host (La Scola et al., 2008).

However, regardless of the way of entry or co-infection of eukaryotes (amoebae and flagellates) with giant viruses and virophages, the infection reduces the number of the hosts. This decrease was demonstrated to be greater when infection was caused only by a giant virus 
a

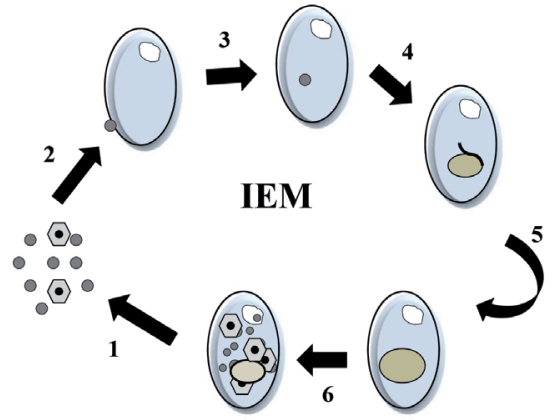

c Predator-prey system

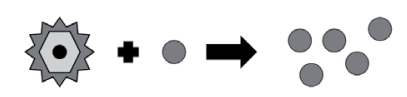

b

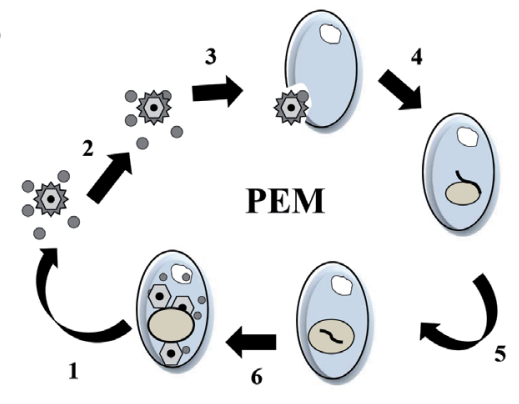

d

Direct contact mechanism

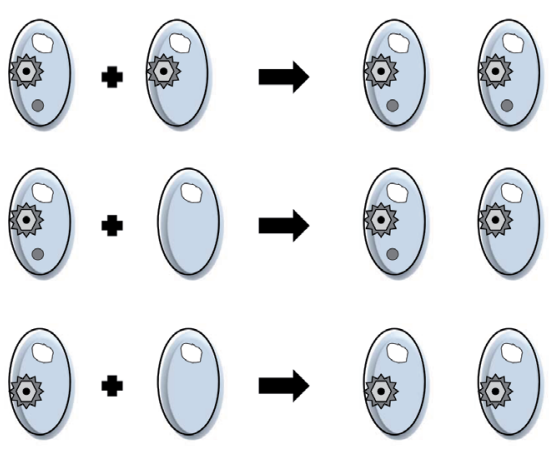

Figure 1. Virophage and giant virus co-infection lifecycle.

(A) Independent entry mode - IEM (Taylor et al., 2014). Step 1: A free virophage and a giant virus following a host's lysis. Step 2: A free virophage enters the host. Step 3: A free giant virus enters the host - amoeba. Step 4: The viral particles lose capsids. Step 5: The virophage genome enters the viral factory (viral factory expands). Step 6: The virophages leave the viral factory and wait for the lysis (by host). (B) Paired entry mode - PEM (Taylor et al., 2014). Step 1: A free virophage and a giant virus following a host's lysis. Step 2: A virophage and a giant virus entangle. Step 3: The entanglement enters the host (co-infection). Step 4: The viral particles lose capsids. Step 5: The virophage genome enters the viral factory (viral factory expands). Step 6: The virophages leave the viral factory and wait for the lysis (by host). (C) Predator-prey system (Yau et al., 2011). A virophage replicates via the infection and lysis of a giant virus, in the absence of a host. (D) Direct contact mechanism (Wodarz, 2013). Replication of a virophage and a giant virus, where the free viral particles are not released into the environment.

compared to when infection was caused by a virus and a virophage. This finding shows that virophages are infection factors, protecting amoebae and flagellates against giant viruses. Infection of a giant virus with a virophage was shown to reduce the mortality of the infected amoebae and flagellates and to cause abnormal shape of the infected giant viruses (Campos et al., 2014; Gaia et al., 2014). This was reported in a study of Zamilon virophage that infects the Mont1 virus (Gaia et al., 2014). In a study of the Mont1 giant virus, a sequence was isolated that was not found in (classic) viruses. It was called MIMIvirus VIrophage Resistant Element (MIMIVIRE) and it the virus against Zamilon infection (Lavasseuer et al., 2016). The system is also suggested (Lavasseuer et al., 2016) to be present in other Mimiviridae giant viruses. It is similar to CRISPR/Cas mechanism, which is widespread in bacteria and archaea (Lavasseuer et al., 2016) and based on the short palindromic repeats created after RNA transcription, which are then used as a guide for enzymatic proteins, including helicases and nucleases, for cleaving of the foreign nucleic acids. After cleavage, the foreign DNA with palindromic sequences is included in-between the repeats. In the next infection of bacteria and archaea with a similar factor, they can act directly against the foreign DNA, e.g. DNA of bacteriophages. A study on MIMIVIRE system in the Mont1 virus showed 28 nucleoid sequence repeats that did not contain open reading frames (ORFs) (Lavasseuer et al., 2016). Although the MIMIVIRE system, defined as a model of the giant virus immunity against virophage infection, can follow a different mechanism (Claverie et al., 2016), the authors of the study gave no further details.

Regardless of whether the elements of immunity against virophages exist in the giant viruses, the infection of giant viruses with virophages lower their number, which ultimately protects their hosts - protozoa (Taylor et al., 2014). The presence of Sputnik virophage infection of the ACMV Mamavirus was demonstrated to reduce the count of $A$. polyphaga amoebae by $13 \%$ less then when infected with ACMV Mamavirus only (Taylor et al., 2014). A similar picture was observed in a culture of Cafateria roenbergensis flagellate infected with Crov and Mavirus virophages (Fischer et al., 2011). Therefore, the virophages were called the friends of the giant virus hosts (eukaryotes and algae), which differentiates them from typical satellite- or satellite-like viruses, which they are often compared to (Table 2). Through destruction of the giant viruses, the virophages participate in a biological loop. It was recorded in Antarctica lakes that they affect the growth of blooming algae (Santini et al., 2013; Yau et al., 2011). Another model of the giant viruses and virophages spread, presented by Wodarz (Wodarz, 2013) is in opposition to that presented by Taylor and coworkers (Taylor et al., 2014) and describes this phenomenon 
through a direct contact of a virophage and a giant virus, which does not include the presence of a "free" giant virus or virophage in environment (Fig. 1d).

The virophages were shown to have a positive effect on bacteria (Slimani et al., 2013). Superinfection of eukaryotes with a giant virus and BABL1 bacteria increases the count of BABL1 and virophages and reduces the number of giant viruses. This finding suggests that through their effect on giant viruses, the virophages affect the count of BABL1 bacteria, probably due to bacteria and giant viruses competing for the host (Slimani et al., 2013). Since the effect of the virophages on the giant viruses is that the count of the latter is reduced, it provides better conditions for bacteria to thrive (Slimani et al., 2013). The number of virophages in aqueous environment depends on water temperature and its chemical composition, just like in case of the bacteriophages. This correlation was demonstrated in Yellowstone Lake water, where the number of virophage metagenomes correlated with water temperature and sun exposure (Zhou et al., 2015). Yet more experimental data on the co-infection and dynamics of virophage presence in the giant viruses is needed to accurately describe the process of virophages replication, as well as the mechanism of entry and interaction with a giant virus and their host.

\section{SUMMARY}

The discovery and isolation of the virophages and their hosts - giant viruses has brought some novel facts into virology. The analysis of available data on virophages and giant viruses, evokes a question if the current taxonomic division into three domains (bacteria, archaea and eukaryotes) is indeed a right one. The properties of virophages and giant viruses, that have not been previously identified in the infection factors, may suggest that this division lacks precision. The data concerning virophages, giant viruses and their interactions, including a novel mechanism of the giant viruses' defense systems, constitute some of the new discoveries of biology of the 21 st century and reveals the imperfections of the current three domains division of living organisms.

\section{REFERENCES}

Abergel Ch, Legendre M, Ckaverir JM (2015) The rapidly expanding universe of giant viruses: Mimivirus, Pandovirus, Pithovirus and Mollivirus. FEMS Microbiol 39: 779-796. http://doi.org/10.1093/ femsre/fuv037

Almeida GM, Silva LC, Colson P, Abrahao JS (2017) Mimivirus and the human interferon system; viral evasion of classical antiviral activities, but inhibition by a novel interferon- $\beta$ regulated immunomodulatory pathway. J Interferon Cytokine Res 37: 1-8. http://doi. org/10.1089/jir.2016,0097

Baudoux AC, Brussaard CPD (2005) Characterization of different viruses infecting the marine harmful algal bloom species Phaeocystis globosa. Virology 341: 80-90. http://doi.org/10.1016/j.virol.2005.07.002

Beklitz M, Colson P, La Scola B (2016) The expanding family of virophages. Viruses 8: E317. http://doi.org/10.3390/v8110317

Beklitz M, Verneaum J, Benamar S, Raoult D, La Scola B, Colson P (2015) A new Zamilion-like virophage partial genome assembled from a bioreactor metagenome. Front Microbiol 6: 1308. http://doi. org $/ 10.3389 /$ fmicb. 2015.01308

Boughalmi M, Pagnier I, Aherfi S, Colson P, Raoult D, La Scola B (2013) First isolation of a Marseillevirus in the diptera syrphidae Eristalis tenax. Intervirology 56: 386-394. http://doi. org $/ 10.1159 / 000354560$

Campos RK, Boratto PV, Assis FL, Aguiar ER, Silva LC, Albarnaz JD, Dornas FP, Trindade GS, Ferreira PP, Marques JT, Robert C, Raoult D, Kroon EG, La Scola B, Abrahao JS (2014) Samba virus: a novel mimivirus from a giant rain forest, the Brazilian Amazon. Virology J 11: 95 http://doi.org/10.1186/1743-422X-11-95
Claverie JM, Abergel Ch (2009) Mimivirus and its virophage. Annu Rev Genet 43: 49-66. http://doi.org/10.1146/annurev-genet-102108-134255

Claverie JM, Abergel Ch (2016) CRISPR-Cas-like system in giant viruses: why MIMIVIRE is not likely to be an adaptive immune system. Virolo Sin 31: 193-196. http://doi.org/10.1007/s12250-016-3801-x

Claverie JM, Grzela R, Lartigua A, Nitsche S, Vacetel J, Ogata H, Abergel Ch (2009) Mimivirus and Mimiviridae: giant viruses with an increasing number of potential hosts, including corals and sponges. $J$ Invertebr Pathol 10: 172-180. http://doi.org/10.1016/j.jip.2009.03.011

Claverie JM, Ogata H, Audic S, Abergel Ch, Suhre K, Fourtnier P-E (2006) Mimivirus and the emerging concept of 'giant' virus. Virus Res 117: 133-144. http://doi.org/10.1016/j.virusres.2006.01.008

Colson P, Raoult D (2010) Gene repertoire of amoeba-associated giant virus. Intervirology 53: 330-343. http://doi.org/10.1159/000312918

Desnues C, Boyer M, Raoult D (2012) Sputnik, a virophage infecting the viral domain of life. Adv Virus Res 82: 63-89. http://doi. org/10.1016/B978-0-12-394621-8.00013-3

Desnues C, Raoult D (2010) Inside the lifestyle of the virophage. Intervirology 53: 293-303. http://doi.org/10.1159/000312914

Desnues Ch, La Scola B, Yutin N, Fournous G, Robert C, Azza S, Jardot P, Monteli S, Campocasso A, Koonin EV, Raoult D (2012) Provirophages and transpositions as the diverse Fischer MG, Suttle CA (2011) A virophage at the origin of large DNA transposons. Science 332: 231-234. http://doi.org/10.1126/science.1199412

Dos Santos RN, Campos FS, Medeiros de Albuquerque NR, Finoketti F, Côrrea RA, Cano-Ortiz L, Assis FL, Arantes TS, Roehe PM, Franco AC. (2016) A new marseillevirus isolated in Southern Brazil from Limnoperna fortunei. Sci Rep 6: 35237. http://doi.org/10.1038/ srep 35237

Fischer MG, Suttle CA (2011) A virophage at the origin of large DNA transposons. Science 332: 231-234. http://doi.org/10.1126/science. 1199412

Fischer MG, Hackl T (2016) Host genome integration and giant virusinduced reactivation of the virophage mavirus. Nature 540: 288-291. http://doi.org/10.1038/nature20593

Gaia M, Benamar S, Boughalmi M, Pagnier I, Croce O, Colson P, Raoult D, La Scola B (2014) Zamilon, a new virophage with Mimiviridae host specificity. PLoS One 9: e94923. http://doi. org/10.1371/journal.pone.0094923

Gaia M, Pagnier I, Campocasso A, Fournous G, Raoult D, La Scola B (2013) Broad spectrum of mimiviridae virophage allows its isolation using mimivirus reporter. PLoS One 8: e61912. http://doi. org/10.1371/journal.pone.0061912

Gong Ch, Zhang W, Zhou X, Wang H, Sun G, Xiao J, Pan Y, Yan S, Wang Y (2016) Novel virophages discovered in a freshwater lake in China. Front Microbiol 7: 5. http://doi.org/10.3389/fmicb.2016.00005

Krupovic M, Kuhn JH, Fischer MG (2016) A classification system for virophages and satellite viruses. Arch Virol 161: 233-247. http://doi. org/10.1007/s00705-015-2622-9

Kutikhin AG, Yuzhalin AE, Brusina EB (2014) Mimiviridae, Marseilleviridae, and virophages as emerging human pathogens causing healthcare-associated infections. GMS Hyg Infect Control 9: Doc16. http://doi.org/10.3205/dgkh000236

La Scola B (2014) Looking at protists as a source of pathogenic viruses. Microb Pathog 77: 131-135. http://doi.org/10.1016/j.micpath.2014.09.005

La Scola B, Audic S, Robert C, Jungang L, de Lamballerie X, Drancourt M, Birtles R, Claverie JM, Raoult D (2003) A giant virus in amoebae. Science 299: 2033. http://doi.org/10.1126/science.1081867

La Scola B, Desnues Ch, Pagnier I, Robert C, Barrassi L, Fournous G, Merchat M, Suzan-Monti M, Forterre P, Koonin E, Raoult D (2008) The virophage as a unique parasite of the giant mimivirus. Nature 455: 100-105. http://doi.org/10.1038/nature07218

La Scola B, Marrie TJ, Auffray JP, Raoult D (2005) Mimivirus in pneumonia patients. Emerg Infect Dis 11: 449-452. http://doi. org/10.3201/eid1103.040538

Levasseuer A, Beklitz M, Chabriere E, Pontarotti P, La Scola B, Raoult $\mathrm{D}$ (2016) Mimivire is a defense system in mimivirus that confers resistance to virophage. Nature 531: 249-252. http://doi.org/10.1038/ nature17146

Marie V, Lin J (2016) Cannibalistic viruses in the aquatic environment: role of virophages in manipulating microbial communities. Int J Environ Sci Technol 13: 2097-2104. http://doi.org/10.1007/s13762-0161027-y

Oh S, Yoo D, Liu WT (2016) Metagenomics reveals a novel virophage population in a Tibetan mountain lake. Microbes Environ 31: 173-177. http://doi.org/10.1264/jsme2.ME16003

Raoult D, Audic S, Robert C, Abergel Ch, Renesto P, Ogata H, La Scola B, Suzan M, Claverie JM (2004) The 1,2-megabase genome sequence of Mimivirus. Science 306: 1344-1350. http://doi. org/10.1126/science.1101485

Raoult D, Boyer M (2010) Amoebae as genitors and reservoirs of giant viruses. Intervirology 53: 321-329. http://doi.org/10.1159/000312917

Rodriggues RA, dos Santos Silva LK, Dornas FP, de Oliveira DB, Magelhaes TF, Santos DA, Costa AO, de Macedo Farias L, Magelhaes 
PP, Bonjardim CA, Kroon EG, La Scola B, Cortines JR, Abrahao JS (2015) Mimivirus fibrils are important for viral attachment to microbial world by a diverse glycoside interaction repertoire. J Virol 89: 11812-11819. http://doi.org/10.1128/JVI.01976-15

Saadi H, Pagnier I, Colson P, Cherif JK, Beji M, Boughalmi M, Azza S, Armstrong N, Robert C, Fournous G, La Scola B, Raoult D (2013) First isolation of Mimivirus in a patient with pneumonia. Clin Infect Dis 57: 127-134. http://doi.org/10.1093/cid/cit354

Saadi H, Reteno DG, Colson P, Aherfi S, Minodier P, Pagnier I, Raoult D, La Scola B (2013) Shan virus: a new Mimivirus isolated from stool of a Tunisian patient with pneumonia. Intervirology 56: 424-429. http://doi.org/10.1159/000354564

Santini S, Jeudy S, Bartoli J, Poirot O, Lescot M, Abergel Ch, Barbe V, Wommack KE, Noordeloos AA, Brussaard CP, Claverie JM (2013) Genome of Phaeocystis globosa virus PgV-16T highlights the common ancestry of the largest known DNA viruses infecting eukaryotes. Proc Natl Acad Sci USA 110: 10800-10805. http://doi. org/10.1073/pnas.1303251110

Sharma V, Colson P, Pontarotti P, Raoult D (2016) Mimivirus inaugurated in the $21^{\text {st }}$ century the beginning of a reclassification of viruses. Curr Opin Microbiol 31: 16-24. http://doi.org/10.1016/j. mib.2015.12.010

Slimani M, Pagnier I, Raoult D, La Scola B (2013) Amoebae as battlefields for bacteria, giant viruses, and virophages. J Virol 87: 47834785. http://doi.org/10.1128/JVI.02948-12

Sliwa-Dominiak J, Ogorkiewicz A, Tokarz-Deptuła B, Deptuła W (2016) New virophages: Mavirus and OLV. Med Weter 72: 83-86

Suzan-Monti M, La Scola B, Barrassi L, Raoult D (2007) Ultrastructural characterization of the giant volcano-like virus factor of Acanthamoeba polyphaga Mimivirus. PLoS One 2: e328. http://doi. org/10.1371/journal.pone.0000328

Suzan-Monti M, La Scola B, Raoult D (2006) Genomic and evolutionary aspects of Mimivirus. Virus Res 117: 145-155. http://doi. org/10.1016/j.virusres.2005.07.011

Taylor BP, Cortez MH, Weitz JS (2014) The virus of my virus is my friend: ecological effects of virophage with alternative modes of coinfection. I Theor Biol 354: 124-136. http://doi.org/10.1016/j. jtbi.2014.03.008

Tokarz-Deptuła B, Sliwa-Dominiak J, Adamiak M, Kubis M, Ogorkiewicz A, Deptuła W (2015) Virophages-new biological elements. Post Mikerobiol 54: 217-223

Tokarz-Deptuła B, Sliwa-Dominiak J, Kubis M, Deptuła W (2013) APMV Mimivirus, mamavirus and its virophage - structure and characteristics. Post Mikerobiol 52: 105-109

Wilson WH, Van Etten JL, Allen MJ (2009) The Phycodnaviridae: the story of how tiny giants rule the world. Curr Top Microbiol Immunol 328: $1-42$

Wodarz D (2013) Evolutionary dynamics of giant viruses and their virophages. Ecol Evol 3: 2103-2115

Xiao C, Chipman PR, Battisti AJ, Bowman VD, Renesto P, Raoult D, Rossmann MG (2005) Cryo-electron microscopy of the giant Mimivirus. J Mol Biol 353: 493-496. http://doi.org/10.1016/j. jmb.2005.08.060

Xiao C, Kuznetsov YG, Sun S, Hafenstein SL, Kostyuchenko VA, Chipman PR, Suzan-Monti M, Raoult D, McPherson A, Rossmann MG (2009) Structural studies of the giant Mimivirus. PLoS Biol 7: e92. http://doi.org/10.1371/journal.pbio.1000092

Yau S, Lauro FM, DeMaere MZ, Brown MV, Thomas T, Reftery MJ, Andrews-Pfannkoch C, Lewis M, Hoffman JM, Gibson JA, Cavicchioli R (2011) Virophage control of Antarctic algal host-virus dynamics. Proc Natl Acad Sci USA 108: 6163-6168. http://doi. org/10.1073/ pnas.1018221108

Yutin N, Kapitonov VV, Koonin EV (2015) A new family of hybrid virophages from an animal gut metagenome. Biol Direct 10: 19 . doi:10:1910.1186/s13062-015-0054-9

Zhou J, Sun D, Childers A, McDermott TR, Wang Y, Liles MR (2015) Three novel virophage genomes discovered from Yellowstone Lake metagenomes. J Virol 89: 1278-1285. http://doi.org/10.1128/ JVI.03039-14

Zhou J, Zhang W, Yan S, Xiao J, Zhang Y, Li Y, Pan Y, Wang Y (2013) Diversity of virophages in metagenomic date sets. J Virol 87: 4225-4236. http://doi.org/10.1128/ JVI.03398-12 